Influence of organic and mineral fertilizers on agronomic traits of potato

Utjecaj gnojidbe organskim i mineralnim gnojivima na agronomska svojstva krumpira

Pospišil, A., Pospišil, M., Švencbir, M.

Poljoprivreda/Agriculture

ISSN: $1848-8080$ (Online)

ISSN: 1330-7142 (Print)

http://dx.doi.org/10.18047/poljo.23.1.2

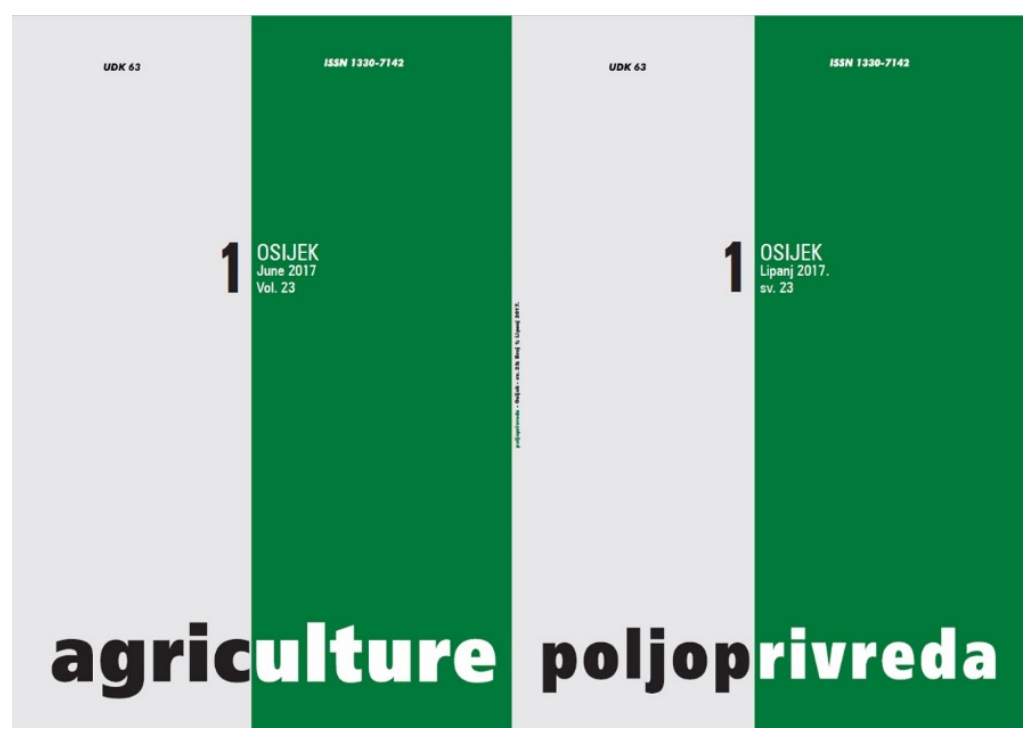

Poljoprivredni fakultet u Osijeku, Poljoprivredni institut Osijek Faculty of Agriculture in Osijek, Agricultural Institute Osijek 
ISSN $1330-7142$

UDK: $635.21: 631.811 / .87$

DOI: $10.18047 /$ poljo.23.1.2

\section{INFLUENCE OF ORGANIC AND MINERAL FERTILIZERS ON AGRONOMIC TRAITS OF POTATO}

Pospišil, A., Pospišil, M., Švencbir, M.

Original scientific paper
Izvorni znanstveni članak

SUMMARY

The aim of research conducted on the experimental field of Faculty of Agriculture in Zagreb during 2012 and 2013 was to determine the influence of organic and mineral fertilizers on the agronomic properties of potato. The research comprised two organic fertilizers, Biorex and Italpollina, mineral fertilizers and a combination of mineral and organic fertilizers. The highest yield of tuber and dry matter was achieved when the fertilization was conducted using solely mineral fertilizers or a combination of mineral and organic fertilizers. Fraction 35-55 mm had the highest share in the total tuber yield. Fertilization with mineral fertilizers and with the combination of mineral and organic fertilizers had a positive effect on the share of fractions $>55 \mathrm{~mm}$ particularly in favourable 2012 year.

Key-words: potato, agronomic traits, mineral and organic fertilizers

\section{INTRODUCTION}

Potato is one of the most important nutritional plants in the world. Its cultivation is limited by environmental conditions, and balanced fertilization with both mineral and organic fertilizers is necessary for its successful production. In order to achieve high yield of potato, a large quantity of nutrients is needed (Harris, 1992; Marschner et al., 1996; Haase et al., 2007). Kołodziejczyk (2014) states that the presence of nitrogen of up to $180 \mathrm{~kg} / \mathrm{ha}$ has a positive influence on potato yield, but also on a market-sized tuber. However, the usage of nitrogen in large quantities is not acceptable from agronomical, ecological or economic standpoint (Poljak, 2007). Although an increased quantity of nitrogen had a positive influence on potato yield, dry matter content and protein content in some potato varieties, Fontes et al. (2010) state that the efficiency of nitrogen usage declines as its quantity increases. The same authors claim that the profitability of nitrogen usage depends on the potato variety and the price of nitrogen fertilizer. Poljak et al. (2011) state that the increase in nitrogen quantity reduces its absorption efficiency. However, as nitrogen quantity increases up to $150 \mathrm{~kg} / \mathrm{ha}$, the yield of tuber increases as well, while the share of small tuber $(<35 \mathrm{~mm})$ decreases.
Haase et al. (2007) state that the yield of dry matter, the share of tuber fraction $40-65 \mathrm{~mm}$ and the share of tuber larger than $55 \mathrm{~mm}$ depend on fertilization, variety and vegetation year.

Since the application of farmyard manure fertilizer is expensive and limited to areas with livestock production, the use of concentrated organic fertilizer contributes to the increase in tuber yield and soil fertility. However, nutrients in mineral fertilizers are more accessible and efficient than those in organic fertilizers (Bagdoniene et al., 1998). The combination of mineral fertilizers and farmyard manure has a positive influence on potato tuber yield, but the content of dry matter and starch is higher when fertilization is carried out solely with mineral fertilizers (Baniuniene i Zekaite, 2008). Haase et al. (2007) obtained the highest potato tuber yield when using a combination of mineral potassium and organic nitrogen. Cattle manure did not have a consistent effect on the yield of potato tuber during different vegetation seasons which makes it an unreliable source of nitrogen for plants.

The aim of this research was to determine the influence of organic and mineral fertilizers on the agronomic properties of potato.

Prof. Dr. Ana Pospišil (apospisil@agr.hr), Prof. Dr. Milan Pospišil, Mario Švencbir, M. Eng. - University of Zagreb, Faculty of Agriculture, Department of Field Crops, Forage and Grassland, Svetošimunska cesta 25, 10000 Zagreb, Croatia 


\section{MATERIAL AND METHODS}

The research was carried out on the experimental field of Faculty of Agriculture in Zagreb during 2012 and 2013. The research comprised two organic fertilizers, Biorex and Italpollina, mineral fertilizers and a combination of mineral and organic fertilizers. Biorex is processed manure that contains $2.8 \% \mathrm{~N}, 3 \% \mathrm{P}_{2} \mathrm{O}_{5}, 2 \%$ $\mathrm{K}_{2} \mathrm{O}$ and $65 \%$ organic matter. Italpollina is dehydrated poultry manure that contains $4 \% \mathrm{~N}, 4 \% \mathrm{P}_{2} \mathrm{O}_{5}$ and $4 \% \mathrm{~K}_{2} \mathrm{O}$ in the organic matter. Mineral fertilizers used were NPK 7:20:30, KAN $27 \% \mathrm{~N}$ and $60 \%$ potassium salt.

Fertilization variants were the following:

1. Control - no fertilizer

2. Biorex $-1.5 \mathrm{t} / \mathrm{ha}$

3. Italpollina $-1.5 \mathrm{t} / \mathrm{ha}$

4. NPK 7:20:30 + KAN (total: $160 \mathrm{~kg} / \mathrm{ha} \mathrm{N}, 140 \mathrm{~kg}$ / ha $\mathrm{P}_{2} \mathrm{O}_{5}$ and $210 \mathrm{~kg} / \mathrm{ha} \mathrm{K}_{2} \mathrm{O}$ )

5. Biorex $1.5 \mathrm{t} / \mathrm{ha}+$ NPK 7:20:30 + KAN 27\% N lessened for nutrients added with Biorex (total: $160 \mathrm{~kg} / \mathrm{ha} \mathrm{N}, 140 \mathrm{~kg} / \mathrm{ha} \mathrm{P}_{2} \mathrm{O}_{5}$ and $210 \mathrm{~kg} / \mathrm{ha} \mathrm{K}_{2} \mathrm{O}$ )

6. Italpollina 1.5 t/ha + NPK 7:20:30 + KAN 27\% N lessened for nutrients added with Biorex (total: $160 \mathrm{~kg} / \mathrm{ha} \mathrm{N}, 140 \mathrm{~kg} / \mathrm{ha} \mathrm{P}_{2} \mathrm{O}_{5}$ and $210 \mathrm{~kg} / \mathrm{ha} \mathrm{K}_{2} \mathrm{O}$ )

In the initial tillage $80 \mathrm{~kg} / \mathrm{ha} \mathrm{N}, 140 \mathrm{~kg} / \mathrm{ha} \mathrm{P}_{2} \mathrm{O}_{5}$ and $210 \mathrm{~kg} / \mathrm{ha} \mathrm{K} \mathrm{K}_{2} \mathrm{O}$ (variants 4, 5 and 6) were used. Before the potato was planted, Biorex and Italpollina were applied in the quantity of $1.5 \mathrm{t}$ /ha (variants $2,3,5$, and 6 ) and nitrogen in the quantity of $40 \mathrm{~kg} / \mathrm{ha}$ (variants 4,5 and 6). During ridging of the potato, $40 \mathrm{~kg} / \mathrm{ha}$ of nitrogen were applied in the form of KAN 27\% N (variants 4, 5 and 6).

Medium early potato variety Red lady (C2 seed reproduction) was used in the research. The experiment was set up in random block design in five repetitions. Plot size was $15.4 \mathrm{~m}^{2}$ (4 rows $\times 0.70 \mathrm{~m}$ distance between rows $\times 5.5 \mathrm{~m}^{2}$ row length). Sugar beet was grown as forecrop. Planting was conducted on March 23rd 2012 and April 16th 2013. The distance within the row was $30 \mathrm{~cm}$, while the distance between the rows was $70 \mathrm{~cm}$. Ridging and topdressing were conducted on May 24th 2012 and May 24th 2013. Protection from weeds was conducted using Sencor WG 70 herbicide (active ingredient metribuzin $700 \mathrm{~g} / \mathrm{kg}$ ) in the quantity of $1 \mathrm{~kg} / \mathrm{ha}$ and Stomp $330 \mathrm{E}$ herbicide (active ingredient pendimethalin $330 \mathrm{~g} / \mathrm{l}$ ) in the quantity of $4 \mathrm{l} / \mathrm{ha}$. During vegetation fungicides Ridomil Gold MZ 68 WP (active ingredient metalaxil-M $40 \mathrm{~g} / \mathrm{kg}$ and mancozeb $640 \mathrm{~g} / \mathrm{kg}$ ) in the quantity of $2.5 \mathrm{~kg} / \mathrm{ha}$ and Quadris (active ingredient azoxystrobin $250 \mathrm{~g} / \mathrm{l}$ ) in the quantity of $1 \mathrm{l} / \mathrm{ha}$ were used for suppression of blight in both years of research. Suppression of Colorado potato beetle was conducted using insecticides Actara 25 WG (active ingredient thiamethoxam $250 \mathrm{~g} / \mathrm{kg}$ ) in the quantity of $80 \mathrm{~g} / \mathrm{ha}$, Rotor $1.25 \mathrm{EC}$ (active ingredient deltamethrin $1.25 \%$ ) in the quantity of $0.6 \mathrm{l} / \mathrm{ha}$ and Mospilan $20 \mathrm{SG}$ (active ingredient acetamiprid $200 \mathrm{~g} / \mathrm{kg}$ ) in the quantity of $0.08 \mathrm{~kg} / \mathrm{ha}$. Potato was harvested on August 23rd 2012 and August 23rd 2013.
The studies were conducted on eutric-brown soil, neutral reaction ( $\mathrm{pH}$ in $\mathrm{KCl} 7.12)$, poorly supplied with humus $(2.2 \%)$, well supplied with nitrogen $(0.125 \%)$, phosphorus and potassium $\left(32.1 \mathrm{mg} \mathrm{P}_{2} \mathrm{O}_{5} / 100 \mathrm{~g}\right.$ of soil and $25.3 \mathrm{mg} \mathrm{K}_{2} \mathrm{O} / 100 \mathrm{~g}$ of soil, respectively).

Tuber number and tuber weight per plant were determined on the sample of 10 plants per plot before harvest. Yield, tuber number and tuber weight per fractions $<35 \mathrm{~mm}, 35-55 \mathrm{~mm}$ and $>55 \mathrm{~mm}$ were determined after harvest. Dry matter content in potato tuber was determined by drying the tuber sample, first at the temperature of $70^{\circ} \mathrm{C}$ and then at the temperature of $105^{\circ} \mathrm{C}$ until constant mass was reached.

The obtained data was analysed with the program MSTAT-C (Michigan State University, 1990).

\section{RESULTS AND DISCUSSION}

In 2012 the highest yield of tuber was achieved with mineral fertilizers (51.55 t/ha), while in 2013 the highest yield was achieved with a combination of mineral fertilizers and Biorex (37.21 t/ha), Tables 1 and 2. The difference in potato tuber yield between varieties fertilized with mineral fertilizers and a combination of mineral and organic fertilizers was not statistically significant. In 2012 the lowest tuber yield was achieved by control variant (32.10 t/ha). In 2013, although the control variant achieved the lowest yield $(26.56 \mathrm{t} / \mathrm{ha})$, the difference in yield between this variant and the variant fertilized with Biorex and Italpollina was not statistically significant. There was no significant difference in the tuber yield using Biorex and Italpolline. However, since the concentration of nutrients in Biorex is lower, it is to be assumed that with a higher amount of Biorex, the difference in yield would be more pronounced.

In 2013 the yield of potato tuber was lower compared to 2012 due to unfavourable weather conditions during vegetation. June and July of 2013 had less precipitation than average, while the mean monthly air temperatures were higher compared to 2012 and longterm average (tables 3 and 4). Márton (2004) states that potato yield is heavily influenced by the interaction between fertilization and quantity and distribution of precipitations. Palmer (2013) mentions weather conditions and preceding crop as factors which have profound effect on tuber yield and quality in organic production. The author also states that nitrogen supply is the main limiting factor of potato yield in ecological systems of production. László (2009) claims that the influence of climate anomalies on potato yield depends on their time of occurrence and length.

In both years of research, variants with different fertilizers showed no difference in dry matter content (Tables 1 and 2). In 2012, dry matter content varied between 26.4 and $27.7 \%$, while in 2013 it varied between 22.3 and $23.9 \%$. Poljak et al. (2007) also state that fertilization with nitrogen did not significantly influence dry matter content in potato tuber. 
Table 1. Tuber yield, dry matter content, dry matter yield, tuber number and weight per plant in 2012

Tablica 1. Prinos gomolja krumpira, sadržaj suhe tvari, prinos suhe tvari gomolja, broj i masa gomolja po biljci u 2012. godini

\begin{tabular}{|l|c|c|c|c|c|}
\hline $\begin{array}{l}\text { Treatment } \\
\text { Varijanta }\end{array}$ & $\begin{array}{c}\text { Tuber yield (t/ha) } \\
\text { Prinos gomolja (t/ha) }\end{array}$ & $\begin{array}{c}\text { Dry matter } \\
(\%) \\
\text { Suha tvar (\%) }\end{array}$ & $\begin{array}{c}\text { Dry matter vield } \\
\text { (t/ha) } \\
\text { Prinos suhe tvari } \\
(t / h a)\end{array}$ & $\begin{array}{c}\text { Tuber number per } \\
\text { plant } \\
\text { Broj gomolja po } \\
\text { biljci }\end{array}$ & $\begin{array}{c}\text { Tuber weight per } \\
\text { plant (g) } \\
\text { Masa gomolja po } \\
\text { biljci (g) }\end{array}$ \\
\hline Control & $32.10 \mathrm{c}$ & 26.4 & $8.45 \mathrm{c}$ & 12.5 & $816 \mathrm{c}$ \\
\hline Biorex & $42.71 \mathrm{~b}$ & 27.7 & $11.80 \mathrm{~b}$ & 13.7 & $1094 \mathrm{ab}$ \\
\hline Italpollina & $41.29 \mathrm{~b}$ & 26.6 & $11.29 \mathrm{~b}$ & 14.5 & $1061 \mathrm{~b}$ \\
\hline Mineral fertilizers & $51.55 \mathrm{a}$ & 26.7 & $13.73 \mathrm{a}$ & 14.9 & $1279 \mathrm{a}$ \\
\hline Mineral fertilizers + Biorex & $49.14 \mathrm{a}$ & 27.1 & $13.33 \mathrm{a}$ & 13.6 & $1257 \mathrm{a}$ \\
\hline Mineral fertilizers + Italpollina & $49.59 \mathrm{a}$ & 27.1 & $13.41 \mathrm{a}$ & 13.4 & $1237 \mathrm{ab}$ \\
\hline
\end{tabular}

Values followed by the same letter within the column are not significantly different at the $5 \%$ level of probability

Table 2. Tuber yield, dry matter content, dry matter yield, tuber number and weight per plant in 2013

Tablica 2. Prinos gomolja krumpira, sadržaj suhe tvari, prinos suhe tvari gomolja, broj i masa gomolja po biljci u 2013. godini

\begin{tabular}{|l|c|c|c|c|c|}
\hline $\begin{array}{l}\text { Treatment } \\
\text { Varijanta }\end{array}$ & $\begin{array}{c}\text { Tuber yield (t/ha) } \\
\text { Prinos gomolja (t/ha) }\end{array}$ & $\begin{array}{c}\text { Dry matter } \\
(\%) \\
\text { Suha tvar (\%) }\end{array}$ & $\begin{array}{c}\text { Dry matter yield } \\
(\mathrm{t} / \mathrm{ha}) \\
\text { Prinos suhe tvari } \\
(\mathrm{t} / \mathrm{ha})\end{array}$ & $\begin{array}{c}\text { Tuber number per } \\
\text { plant } \\
\text { Broj gomolja po } \\
\text { biljci }\end{array}$ & $\begin{array}{c}\text { Tuber weight per } \\
\text { plant (g) } \\
\text { Masa gomolja po } \\
\text { biljci (g) }\end{array}$ \\
\hline Control & $26.56 \mathrm{~b}$ & 23.8 & $6.32 \mathrm{~b}$ & 9.3 & $570 \mathrm{~d}$ \\
\hline Biorex & $27.27 \mathrm{~b}$ & 23.4 & $6.40 \mathrm{~b}$ & 10.6 & $704 \mathrm{bc}$ \\
\hline Italpollina & $29.69 \mathrm{~b}$ & 22.3 & $6.63 \mathrm{~b}$ & 10.0 & $675 \mathrm{~cd}$ \\
\hline Mineral fertilizers & $36.89 \mathrm{a}$ & 23.9 & $8.84 \mathrm{a}$ & 10.6 & $788 \mathrm{ab}$ \\
\hline Mineral fertilizers + Biorex & $37.21 \mathrm{a}$ & 23.7 & $8.83 \mathrm{a}$ & 11.9 & $887 \mathrm{a}$ \\
\hline Mineral fertilizers + Italpollina & $36.14 \mathrm{a}$ & 23.5 & $8.48 \mathrm{a}$ & 11.0 & $824 \mathrm{a}$ \\
\hline
\end{tabular}

Values followed by the same letter within the column are not significantly different at the $5 \%$ level of probability

The highest dry matter yield in 2012 was achieved through fertilization with only mineral fertilizers $(13.73 \mathrm{t} /$ ha) and a combination of mineral fertilizers, Biorex (13.33 t/ha) and Italpollina (13.41 t/ha), Table 1. Conversely, Baniuniene and Zekaite (2008) achieved higher starch and dry matter content with only mineral fertilizers. Fontes et al. (2010) also mention mineral nitrogen as a positive factor on dry matter yield in potato tuber. In 2013, the highest dry matter yield was achieved by the same variants as in 2012 , but due to lower tuber

Table 3. Total month precipitation $(\mathrm{mm})$ during the 2012 and 2013 growing seasons and long-term average (1981-2010) in Zagreb-Maksimir

Tablica 3. Ukupna količina oborina $(\mathrm{mm})$ tijekom vegetacije 2012. i 2013. godine i višegodišnji prosjek (1981.-2010.), Zagreb-Maksimir

\begin{tabular}{|l|r|c|c|}
\hline \multirow{2}{*}{$\begin{array}{l}\text { Month } \\
\text { Mjesec }\end{array}$} & \multicolumn{2}{|c|}{$\begin{array}{c}\text { Growing season } \\
\text { Vegetacijska sezona }\end{array}$} & $\begin{array}{c}\text { Long-term average } \\
\text { Višegodišnji prosjek }\end{array}$ \\
\cline { 2 - 4 } March & 2012 & 2013 & $1981-2010$ \\
\hline April & 4.5 & 121.7 & 54.1 \\
\hline May & 51.3 & 56.1 & 59.5 \\
\hline June & 81.8 & 94.0 & 68.6 \\
\hline July & 127.9 & 48.7 & 97.4 \\
\hline August & 56.3 & 33.2 & 71.4 \\
\hline Total & 331.6 & 145.2 & 96.2 \\
\hline
\end{tabular}

${ }^{*}$ Total quantity of precipitation until harvest yield it varied between 8.48 and $8.84 \mathrm{t} /$ ha (Table 2). Unfavourable weather conditions, more specifically the lack of precipitation in June, July and August and high mean air temperatures during those months, negatively influenced dry matter content in potato tuber (Tables 3 and 4). Other researchers also state that unfavourable weather conditions during vegetation negatively affect yield and quality of potato (Márton, 2004; Baniuniene and Zekaite, 2008).

Table 4. Mean monthly air temperature $\left({ }^{\circ} \mathrm{C}\right)$ during the 2012 and 2013 growing seasons and long-term average (1981-2010) in Zagreb-Maksimir

Tablica 4. Srednje mjesečne temperature $\left({ }^{\circ} \mathrm{C}\right)$ tijekom vegetacije 2012. i 2013. godine i višegodišnji prosjek (1981.-2010.), Zagreb-Maksimir

\begin{tabular}{|l|c|c|c|}
\hline \multirow{2}{*}{$\begin{array}{l}\text { Month } \\
\text { Mjesec }\end{array}$} & \multicolumn{2}{|c|}{$\begin{array}{c}\text { Growing season } \\
\text { Vegetacijska sezona }\end{array}$} & $\begin{array}{c}\text { Long-term average } \\
\text { Višegodišnji prosjek }\end{array}$ \\
\cline { 2 - 4 } March & 2012 & 2013 & $1981-2010$ \\
\hline April & 9.4 & 4.8 & 6.8 \\
\hline May & 12.5 & 13.0 & 11.4 \\
\hline June & 16.7 & 16.4 & 16.5 \\
\hline July & 22.0 & 20.0 & 19.6 \\
\hline August & 24.2 & 23.3 & 21.5 \\
\hline Average & 18.1 & 16.7 & 20.8 \\
\hline
\end{tabular}


In 2012, the highest number of tuber per plant was achieved with mineral fertilizers (14.9), but compared to the other variants, the difference was not statistically significant (Table 1). In 2013, the number of tuber per plant varied from 9.3 in control variant to 11.9 in the combination of mineral fertilizers and Biorex, but the difference was also not statistically significant (Table 2).

In 2012, the highest tuber weight per plant was achieved with mineral fertilizers and a combination of mineral and organic fertilizers, but the obtained number did not significantly differ from when the fertilization was conducted only with Biorex (Table 1). In 2013, significant differences in tuber weight per plant $(p<0.05)$ were achieved between variants with mineral and a combination of mineral and organic fertilizers compared to control variant and the variant with only organic fertilizers (Table 2). In 2013, lower tuber weight per plant was achieved compared to 2012, which negatively impacted the total potato yield. In 2012, tuber weight per plant varied from $816 \mathrm{~g}$ in control variant to $1279 \mathrm{~g}$ in the variant with mineral fertilizers, while in 2013 tuber weight per plant varied from $570 \mathrm{~g}$ in control variant to $887 \mathrm{~g}$ in the variant with a combination of mineral fertilizers and Biorex.

In 2012, the lowest share of the smallest fraction was achieved with a combination of mineral fertilizers and Italpollina, but it did not significantly differ compared to the combination of mineral fertilizers and Biorex, only mineral fertilizers or only Biorex (table 5). In 2013, the lowest share of the smallest fraction was also achieved with the combination of mineral and organic fertilizers and only mineral fertilizers (Table $6)$. The highest share of large tuber $(>55 \mathrm{~mm})$ was achieved with a combination of mineral and organic fertilizers and with only mineral fertilizers (Tables 5 and 6). The share of the largest fraction of tuber in 2012 varied from $4.28 \%$ in control variant to $18.28 \%$ in the variant with mineral fertilizers and Biorex. Due to unfavourable weather conditions in 2013, the share of the largest tuber was lower compared to the previous year, while the share of $35-55 \mathrm{~mm}$ fraction was higher. Other researchers also state that the structure of potato yield is dependent on the environment (MacKerron et al., 1988; Sawicka, 2007).

Table 5. Effect of mineral and organic fertilizers on relative tuber size share in total tuber number in $\mathbf{2 0 1 2}$

Tablica 5. Utjecaj mineralnih i organskih gnojiva na udio frakcija u ukupnome broju gomolja u 2012. godini

\begin{tabular}{|l|c|c|c|}
\hline \multirow{2}{*}{$\begin{array}{l}\text { Treatment } \\
\text { Varijanta }\end{array}$} & \multicolumn{2}{|c|}{$\begin{array}{c}\text { Relative tuber size share in total tuber number (\%) } \\
\text { Udio frakcija u ukupnom broju gomolja (\%) }\end{array}$} \\
\cline { 2 - 4 } & $<35 \mathrm{~mm}$ & $35-55 \mathrm{~mm}$ & $>55 \mathrm{~mm}$ \\
\hline Control & $35.83 \mathrm{a}$ & $59.88 \mathrm{a}$ & $4.28 \mathrm{~d}$ \\
\hline Biorex & $30.58 \mathrm{ab}$ & $59.20 \mathrm{ab}$ & $10.22 \mathrm{bc}$ \\
\hline Italpollina & $38.40 \mathrm{a}$ & $54.03 \mathrm{bc}$ & $7.56 \mathrm{~cd}$ \\
\hline Mineral fertilizers & $30.62 \mathrm{ab}$ & $53.62 \mathrm{bc}$ & $15.77 \mathrm{ab}$ \\
\hline Mineral fertilizers + Biorex & $30.90 \mathrm{ab}$ & $53.31 \mathrm{c}$ & $18.28 \mathrm{a}$ \\
\hline
\end{tabular}

Values followed by the same letter within the column are not significantly different at the $5 \%$ level of probability

Table 6. Effect of mineral and organic fertilizers on relative tuber size share in total tuber number in 2013

Tablica 6. Utjecaj mineralnih i organskih gnojiva na udio frakcija u ukupnome broju gomolja u 2013. godini

\begin{tabular}{|l|c|c|c|}
\hline \multirow{2}{*}{$\begin{array}{l}\text { Treatment } \\
\text { Varijanta }\end{array}$} & \multicolumn{3}{|c|}{$\begin{array}{c}\text { Relative tuber size share in total tuber number (\%) } \\
\text { Udio frakcija u ukupnom broju gomolja (\%) }\end{array}$} \\
\cline { 2 - 4 } & $<35 \mathrm{~mm}$ & $35-55 \mathrm{~mm}$ & 2.11 \\
\hline Control & $38.03 \mathrm{a}$ & 59.87 & 4.14 \\
\hline Biorex & $34.38 \mathrm{ab}$ & 61.49 & 4.05 \\
\hline Italpollina & $34.16 \mathrm{ab}$ & 62.05 & 5.90 \\
\hline Mineral fertilizers & $28.82 \mathrm{bc}$ & 65.29 & 5.25 \\
\hline Mineral fertilizers + Biorex & $27.27 \mathrm{c}$ & 68.21 & 4.78 \\
\hline
\end{tabular}

Values followed by the same letter within the column are not significantly different at the $5 \%$ level of probability

Fraction of $35-55 \mathrm{~mm}$ had the highest share in total potato tuber yield in both years of research (Tables 7 and 8). In 2012, the highest share of this fraction was obtained in control variant, the variant with only organic fertilizers and the variant with a combination of mineral fertilizers and Italpollina. In 2013, the highest share of this fraction was achieved in the variant with a combination of mineral and organic fertilizers. 
Table 7. Effect of mineral and organic fertilizers on relative tuber size distribution in total tuber yield in $\mathbf{2 0 1 2}$

Tablica 7. Utjecaj mineralnih i organskih gnojiva na udio frakcija u ukupnom prinosu gomolja u 2012. godini

\begin{tabular}{|l|c|c|c|}
\hline \multirow{2}{*}{$\begin{array}{l}\text { Treatment } \\
\text { Varijanta }\end{array}$} & \multicolumn{3}{|c|}{$\begin{array}{c}\text { Relative tuber size share in total tuber yield (\%) } \\
\text { Udio frakcija u ukupnom prinosu gomolja (\%) }\end{array}$} \\
\cline { 2 - 4 } & $<35 \mathrm{~mm}$ & $35-55 \mathrm{~mm}$ & $>55 \mathrm{~mm}$ \\
\hline Control & $9.51 \mathrm{a}$ & $79.03 \mathrm{a}$ & $24.46 \mathrm{~d}$ \\
\hline Biorex & $7.65 \mathrm{abc}$ & $68.01 \mathrm{~b}$ & $20.55 \mathrm{~cd}$ \\
\hline Mineral fertilizers & $8.16 \mathrm{ab}$ & $71.29 \mathrm{ab}$ & $36.51 \mathrm{a}$ \\
\hline Mineral fertilizers + Biorex & $6.00 \mathrm{bc}$ & $57.49 \mathrm{c}$ & $40.71 \mathrm{a}$ \\
\hline Mineral fertilizers + Italpollina & $5.71 \mathrm{bc}$ & $53.57 \mathrm{c}$ & $33.12 \mathrm{ab}$ \\
\hline
\end{tabular}

Values followed by the same letter within the column are not significantly different at the $5 \%$ level of probability

Table 8. Effect of mineral and organic fertilizers on relative tuber size distribution in total tuber yield in 2013 Tablica 8. Utjecaj mineralnih i organskih gnojiva na udio frakcija u ukupnom prinosu gomolja u 2013. godini

\begin{tabular}{|l|c|c|c|}
\hline \multirow{2}{*}{$\begin{array}{l}\text { Treatment } \\
\text { Varijanta }\end{array}$} & \multicolumn{2}{|c|}{$\begin{array}{c}\text { Relative tuber size share in total tuber yield (\%) } \\
\text { Udio frakcija u ukupnom prinosu gomolja (\%) }\end{array}$} \\
\cline { 2 - 4 } & $<35 \mathrm{~mm}$ & $35-55 \mathrm{~mm}$ & $>55 \mathrm{~mm}$ \\
\hline Control & $12.32 \mathrm{a}$ & 81.48 & 6.20 \\
\hline Biorex & $11.49 \mathrm{ab}$ & 77.28 & 11.24 \\
\hline Italpollina & $11.47 \mathrm{ab}$ & 75.44 & 13.09 \\
\hline Mineral fertilizers & $8.73 \mathrm{bc}$ & 74.60 & 16.67 \\
\hline Mineral fertilizers + Biorex & $8.34 \mathrm{c}$ & 77.54 & 12.12 \\
\hline
\end{tabular}

Values followed by the same letter within the column are not significantly different at the $5 \%$ level of probability

\section{CONCLUSION}

The use of mineral or a combination of mineral and organic fertilizers had a positive influence on tuber yield, dry matter yield and tuber weight per plant. In both years of research, tuber fraction of $35-55 \mathrm{~mm}$ comprised the highest share of tuber yield. Fertilization with mineral or a combination of mineral and organic fertilizers had a positive influence on tuber fraction $>55 \mathrm{~mm}$, especially in weather-favourable 2012, which resulted in greater tuber yield. Therefore, the use of organic fertilizers in combination with mineral fertilizers is recommended because, apart from the yield increases, they also have a positive effect on soil properties.

\section{REFERENCES}

1. Baniuniene, A., Zekaite, V. (2008): The effect of mineral and organic fertilizers on potato tuber yield and quality. Latvian Journal of Agronomy, 11: 202-2016.

2. Fontes, P.C.R., Braun, H., Busato, C., Cecon, P.R. (2010): Economic optimum nitrogen fertilization rates and nitrogen fertilization rate effects on tuber characteristics of potato cultivars. Potato Research, 53: 167-179. doi: http://dx.doi.org/10.1007/s11540-010-9160-3

3. Harris, P.M. (1992): The potato crop. Chapter 4: Mineral nutrition. Chapman \& Hall, London.
4. Haase, T., Schüler, C., Heß, J. (2007): The effect of different $\mathrm{N}$ and $\mathrm{K}$ sources on tuber nutrient uptake, total and graded yield of potatoes (Solanum tuberosum L.) for processing. European Journal of Agronomy, 26: 187-197. doi: http://doi.org/10.1016/j.eja.2006.09.008

5. Kołodziejczyk, M. (2014): Effect of nitrogen fertilization and microbial preparations on potato yielding. Plant, Soil and Environment, 60(8): 379-386.

6. László, M. (2009): Climate change: precipitation and plant nutrition interactions on potato (Solanum tuberosum L.) yield in North-Eastern Hungary. Geophysical Research Abstracts, 11, EGU, 1398.

7. Marschner, H., Kirkby, E. A., Cakmak, I. (1996): Effect of mineral nutritional status on shoot-root partitioning of photo-assimilates and cycling of mineral nutrients. J. Exp. Botany, 47: 1255-1263.

8. MacKerron, D.K., Marshall, B., Jefferies, R.A. (1988): The distributions of tuber sizes in droughted and irrigated crops of potato. II. Relation between size and weight of tubers and the variability of tuber - size distributions. Potato Research, 31(2): 278-288.

9. Márton, L. (2004): Fertillisation, rainfall and crop yield. Acta Agronomica Hungarica, 52(2): 165-172.

10. Michigen Michigan State University (1990): User's guide to MSTAT-C.

11. Palmer, M.W., Cooper, J., Tétard-Jones, C., ŚrednickaTober, D., Barański, M., Eyre, M., Shotton, P.N., Volakakis, 
N., Cakmak, I., Ozturk, L., Leifert, C., Wilcockson, S. J. Bilsborrow, P. E. (2013): The influence of organic and conventional fertilisation and crop protection practices, preceding crop, harvest year and weather conditions on yield and quality of potato (Solanum tuberosum) in a long-term management trial. European Journal of Agronomy, 49: 83-92.

doi: http://doi.org/10.1016/j.eja.2013.03.004

12. Poljak, M., Herak-Ćustić, M., Horvat, T., Čoga, L., Majić, A. (2007): Effects of nitrogen nutrition on potato tuber composition and yield. Cereal Research Communications, 35: 937-940.

doi: http://doi.org/10.1556/CRC.35.2007.2.193
13. Poljak, M., Lazarević, B., Horvat, T., Karažija, T. (2011): Influence of nitrogen fertilization and plant density on yield and nitrogen use efficiency of the potato (Solanum tuberosum L.). Proceedings 46th Croatian and 6th International Symposium on Agriculture, Opatija, February 14-18, 2011, 667-671.

14. Sawicka, B., Barbaś, P., Kuś, J. (2007): Variability of potato yield and its structure in organic and integrated crop production systems. Electronic Journal of Polish Agricultural Universities 10(1), available Online: http:// www.ejpau.media.pl/volume10/issue1/art-02.html.

\section{UTJECAJ GNOJIDBE ORGANSKIM I MINERALNIM GNOJIVIMA NA AGRONOMSKA SVOJSTVA KRUMPIRA}

\section{SAŽETAK}

Cilj istraživanja provedenih na pokušalištu Agronomskoga fakulteta u Zagrebu tijekom 2012. i 2013. godine bio je utvrditi utjecaj gnojidbe organskim i mineralnim gnojivima na agronomska svojstva krumpira. $U$ istraživanju su bila dva organska gnojiva, Biorex i Italpollina, mineralna gnojiva te kombinacija mineralnih $i$ organskih gnojiva. Najveći prinos gomolja i prinos suhe tvari ostvareni su gnojidbom samo mineralnim gnojivima i mineralnim i organskim gnojivima. U ukupnome prinosu gomolja krumpira najveći udio imala je frakcija 35-55 mm. Gnojidba mineralnim gnojivima i kombinacija mineralnih i organskih gnojiva imale su pozitivan učinak na udio frakcije $>55 \mathrm{~mm}$, osobito u vremenski povoljnijoj 2012. godini.

Ključne riječi: krumpir, agronomska svojstva, mineralna i organska gnojiva

(Received on 14 March 2017; accepted on 24 April 2017 - Primljeno 14. ožujka 2017.; prihvaćeno 24. travnja 2017.) 